\title{
PENGARUH TOOL ROTATION SPEED TERHADAP SIFAT MEKANIK SAMBUNGAN ALUMINIUM PADUAN 6061-T6 PADA PROSES FRICTION STIR WELDING
}

\author{
Tarmizi $^{1}$, Riki Indrawan ${ }^{2}$, Irfan ${ }^{1}$ \\ ${ }^{1}$ Balai Besar Logam dan Mesin-Kementerian Perindustrian \\ Jl. Sangkuriang No.12 Bandung, Indonesia 40135 \\ 2 Jurusan Teknik Metalurgi, Fakultas Teknik, Universitas Jenderal Achmad Yani \\ JI. Terusan Gatot Subroto, Bandung, Indonesia 40285 \\ e-mail:tarmizi@kemenperin.go.id
}

(Naskah diterima: 29-09-2019, Naskah direvisi: 16-10-2019, Naskah disetujui: 30-10-2019)

\begin{abstract}
ABSTRAK
PENGARUH TOOL ROTATION SPEED TERHADAP SIFAT MEKANIK SAMBUNGAN ALUMINIUM PADUAN 6061 T6 PADA PROSES FRICTION STIR WELDING. Pengelasan aduk tekan merupakan proses pengelasan yang baru dikembangkan pada tahun 1991, hingga saat ini berbagai penelitian terus dilakukan untuk menemukan parameter yang dapat menghasilkan sambungan las yang optimum sebagai alternatif proses pengelasan fusi yang masih memiliki beberapa kekurangan. Penelitian ini bertujuan untuk mengetahui pengaruh kecepatan putar tool yang menjadi salah satu parameter penting dalam friction stir welding pada pelat aluminium paduan 6061-T6 dengan tebal $6 \mathrm{~mm}$ terhadap sifat mekanik sambungan las, dengan variasi kecepatan putar yang digunakan 910 rpm, 1175 rpm, 1555 rpm, 1700 rpm dan 2000 rpm untuk mendapatkan parameter yang optimum. Berdasarkan penelitian yang telah dilakukan didapatkan hasil bahwa sambungan las dengan kecepatan putaran $910 \mathrm{rpm}, 1175 \mathrm{rpm}$ dan $1555 \mathrm{rpm}$ tidak terdapat cacat dan memenuhi kriteria sambungan las berdasarkan standar AWS D17.3 sedangkan sambungan las yang memiliki sifat mekanik yang paling optimum yaitu sambungan las dengan kecepatan putar tool 910 rpm karena pengkasaran butir dan larutnya presipitat tidak terlalu signifikan dibandingkan dengan kecepatan putaran lainnya
\end{abstract}

Kata kunci: Pengelasan aduk tekan, pengelasan fusi, kecepatan putar, tool, Aluminium paduan 6061-T6 


\section{ABSTRACT}

THE EFFECT OF TOOL ROTATION SPEED ON MECHANICAL PROPERTIES OF ALUMINUM ALLOY 6061-T6 DURING FRICTION STIR WELDING PROCESS. Friction stir welding is a newly developed welding process in 1991, and various studies have been continuously conducted to determine parameters that can produce optimum welded joints as an alternative to fusion welding process which still shows some imperfections. The purpose of this research is to determine the effect of tool rotation speed, which is one of the important parameters in friction stir welding of 6061-T6 aluminum alloy plate with $6 \mathrm{~mm}$ thickness, on mechanical properties of the welded joints, where variation of rotation speed applied was $910 \mathrm{rpm}, 1175 \mathrm{rpm}, 1555 \mathrm{rpm}, 1700 \mathrm{rpm}$ and $2000 \mathrm{rpm}$. The results show that the welded joint resulted from a speed of $910 \mathrm{rpm}, 1175 \mathrm{rpm}$ and $1555 \mathrm{rpm}$ indicate no defects and satisfy the acceptance criteria of AWS D17.3 standard. The most optimum mechanical characteristic was found for welded joint with rotation tool speed of 910 rpm because grain coarsening and dissolution of precipitate were not too significant when compared to other rotational speeds.

Keywords: Friction Stir Welding (FSW), fusion welding, rotational speed, tool, aluminium alloy 6061-T6 


\section{PENDAHULUAN}

Perkembangan dunia industri saat ini mulai mempertimbangkan material aluminium sebagai bahan utama dalam proses produksi. Ini dikarenakan aluminium dan paduan aluminium termasuk logam ringan yang memiliki kekuatan tinggi, tahan terhadap karat, konduktor listrik yang cukup baik dan aluminium lebih ringan daripada baja[1].

Aluminium seri $6 \mathrm{xxx}$ merupakan salah satu jenis aluminium paduan yang memiliki unsur paduan utama Magnesium (Mg) dan Silicon (Si). Paduan ini termasuk dalam jenis yang dapat diperlaku-panaskan, mempunyai kekuatan dan daya tahan korosi yang cukup baik. Aplikasi paduan ini biasanya digunakan untuk struktur konstruksi, komponen otomotif dan nuclear power plant[2].

Komponen-komponen tersebut memerlukan proses pengelasan dalam proses perakitan dan produksinya. Pengelasan material aluminium pada umumnya menggunakan metode pengelasan GTAW atau GMAW, namun metode tersebut rentan terjadinya cacat seperti porositas, distorsi, dan crack. Untuk mengurangi terjadinya cacat tersebut maka maka dikembangkanlah metode Solid State Welding (SSW) yang memanfaatkan gesekan yang terjadi antara tool dan benda kerja yang akan disambung. Metode ini disebut dengan Friction Stir Welding (FSW) yang diciptakan oleh Wayne Thomas di TWI (The Welding Institute) pada tahun 1991[3]. Proses ini tidak menimbulkan panas berlebih yang dapat menyebabkan terbukanya lapisan oksida sehingga hasil kualitas sambungan akan tetap tahan korosi dan tidak terjadi porositas karena tidak ada udara yang terperangkap seperti pada pengelasan GTAW atau GMAW[4].

FSW adalah sebuah metode pengelasan yang termasuk pengelasan gesek, yang pada prosesnya tidak memerlukan bahan tambah atau pengisi.
Panas yang digunakan untuk melunakkan logam dihasilkan dari gesekan antara tool yang berputar (pin) dengan spesimen yang diam (benda kerja). Pin berputar dengan kecepatan konstan disentuhkan ke material kerja yang telah dicekam. Gesekan antara kedua benda tersebut menimbulkan panas sampai $\pm 80 \%$ dari tititk cair material kerja dan selanjutnya pin ditekankan dan digerakkan searah daerah yang akan dilas. Putaran dari pin bisa searah jarum jam atau berlawanan dengan arah jarum jam[5].

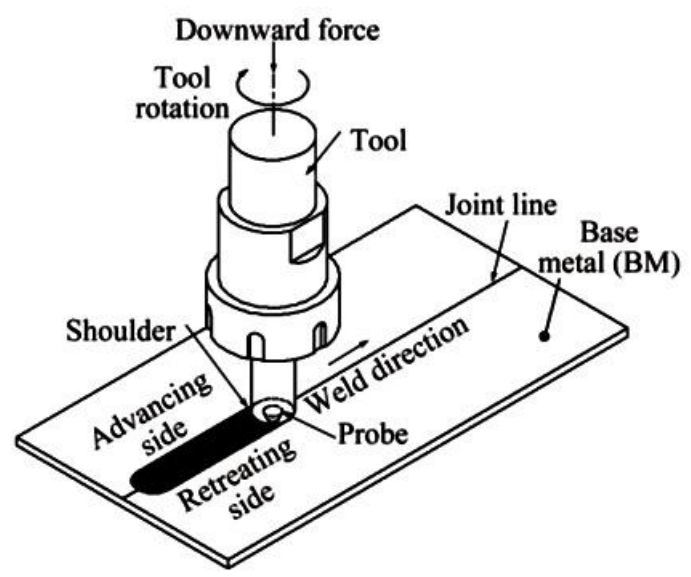

Gambar 1. Skematik proses friction stir welding[6]

Tool yang digunakan pada proses FSW harus mempunyai titik cair dan kekerasan yang lebih dibandingkan dengan material kerja. Pengelasan dengan metode FSW bisa digunakan untuk menyambungkan material yang sama (similar metal) ataupun material yang tidak sama (dissimilar metal) seperti baja dengan baja tahan karat, alumunium dengan kuningan dan memungkinkan untuk mengelas kombinasi material lain yang tidak dapat di las dengan menggunakan metode pengelasan yang lain. Parameter pengelasan yang digunakan harus disesuaikan sedemikian rupa, sehingga pengurangan volume dari tool ketika terjadi gesekan dengan material kerja bisa diperkecil. Hal ini bertujuan untuk menjaga masukan panas yang konstan sepanjang 
proses pengelasan[7]. Pada proses FSW untuk mendapatkan kualitas sambungan yang baik harus memperhatikan beberapa hal seperti tool geometry, parameter proses, temperatur dan benda kerja yang digunakan. Hal tersebut supaya pada daerah terpengaruh panas (HAZ) tidak terjadi perubahan sifat mekanik yang drastis dibanding logam induknya akibat panas yang terjadi pada saat pengelasan[8].

Penelitian Al-Murshdy menjelaskan kenaikan kekuatan tarik disebabkan peningkatan kecepatan putar tool dan penurunan kecepatan pengelasan tetapi peningkatan kecepatan putar secara terus menerus akan menurunkan kekuatan tarik akibat peningkatan panas dan terjadinya pertumbuhan butir baru[9]. Hasil penelitian L. Commin dkk menjelaskan kenaikan kecepatan putar tool atau penurunan kecepatan pengelasan akan meningkatkan panas yang dihasilkan selama proses dan mendorong terjadinya pertumbuhan butir[10]. Sedangkan dalam penelitian Shanmuga dan Murugan melaporkan bahwa peningkatan kecepatan putar tool atau kecepatan pengelasan pada sambungan beda aluminium mengarah pada peningkatan kekuatan tarik sampai pada kuat tarik maksimum kemudian menurun[11].

Pankaj Sharma dan Deepak Bhati melakukan penelitian tentang pengaruh tool rotation speed dan sudut kemiringan pada proses pengelasan FSW Al 6075 dengan menggunakan cylinder smooth tool dan ketebalan material sebesar $6 \mathrm{~mm}$. Dari penelitian tersebut didapatkan hasil bahwa nilai kekerasan tertinggi yaitu pada kecepatan putaran tool $3050 \mathrm{rpm}$ dan sudut kemiringannya sebesar $3^{\circ}$. Sedangkan kekuatan tarik yang paling tinggi pada putaran $1950 \mathrm{rpm}$ dan sudut kemiringannya $3^{\circ}[12]$. Menurut N. Dialami dkk dengan temperatur yang lebih tinggi material akan jadi lebih lunak dan aliran material di belakang tool dengan sudut kemiringan tool besar akan mencegah munculnya cacat[13].
Menurut J. Q. N. Li and H. J. Liu kenaikan kecepatan pengelasan sampai $200 \mathrm{~mm} / \mathrm{min}$ tidak terdapat cacat dan ukuran masingmasing daerah las semakin kecil dan ukuran butir semakin besar sampai kecepatan pengelasan $100 \mathrm{~mm} / \mathrm{min}$ dan kembali mengecil setelahnya. Sedangkan perubahan kekerasan tidak signifikan pada stir zone[14].

Pada proses FSW, untuk mendapatkan kualitas dan kekuatan sambungan yang baik tidak mudah dilakukan. Karena parameter proses pengelasannya harus disesuaikan dengan jenis sambungan yang diinginkan, material yang disambung, desain dan material tool. Dan parameter tersebut berbeda antara yang satu dengan yang lainnya sehingga tidak dapat diaplikasikan pada semua material.

Kegiatan penelitian ini difokuskan pada pengaruh tool rotation speed terhadap sifat mekanik sambungan aluminium paduan 6061-T6 pada proses FSW dengan tool dan material yang digunakan sebagai basemetal berbeda dari penelitian sebelumnya dan kecepatan putar tool yang digunakan dibawah 2000 rpm. Penelitian ini bertujuan untuk mendapatkan parameter yang optimum pada proses FSW aluminium 6061-T6 akibat pengaruh kecepatan putar tool terhadap sifat mekanik dan struktur mikro hasil sambungan las. Proses pengelasan dilakukan pada material aluminium seri 6061-T6 yang aplikasinya banyak digunakan pada struktur konstruksi, komponen otomotif dan nuclear power plant[15,16].

\section{METODOLOGI}

Tahapan yang dilakukan dalam penelitian proses FSW ditunjukkan pada Gambar 2. Penelitian FSW yang dilakukan di Balai Besar Logam dan Mesin Bandung menggunakan mesin milling vertikal merk $G$ Dufour dengan daya motor sebesar $6,6 \mathrm{~kW}$ mempunyai kecepatan putar 24-2000 rpm dan kecepatan potong berkisar 
10-900 $\mathrm{mm} / \mathrm{min}$. Material yang disambung adalah alumunium 6061-T6 ketebalan $6 \mathrm{~mm}$ dengan ukuran $305 \mathrm{~mm} \times 125 \mathrm{~mm}$ dan tipe sambungan butt joint menggunakan tool dengan variasi kecepatan putar 910, 1175, 1555, 1700 dan 2000 rpm. Kecepatan pengelasan yang digunakan $29 \mathrm{~mm} / \mathrm{min}$. Perkakas yang digunakan pada proses FSW alumunium 6061-T6 terbuat dari material tool steel AISI $\mathrm{H} 13$ berbentuk silinder dengan panjang shoulder $26 \mathrm{~mm}$ dan diameter shoulder $20 \mathrm{~mm}$ serta panjang pin 5,6 mm menggunakan ulir M6x1 counter clockwise. Bentuk tool yang digunakan seperti ditunjukkan Gambar 3.

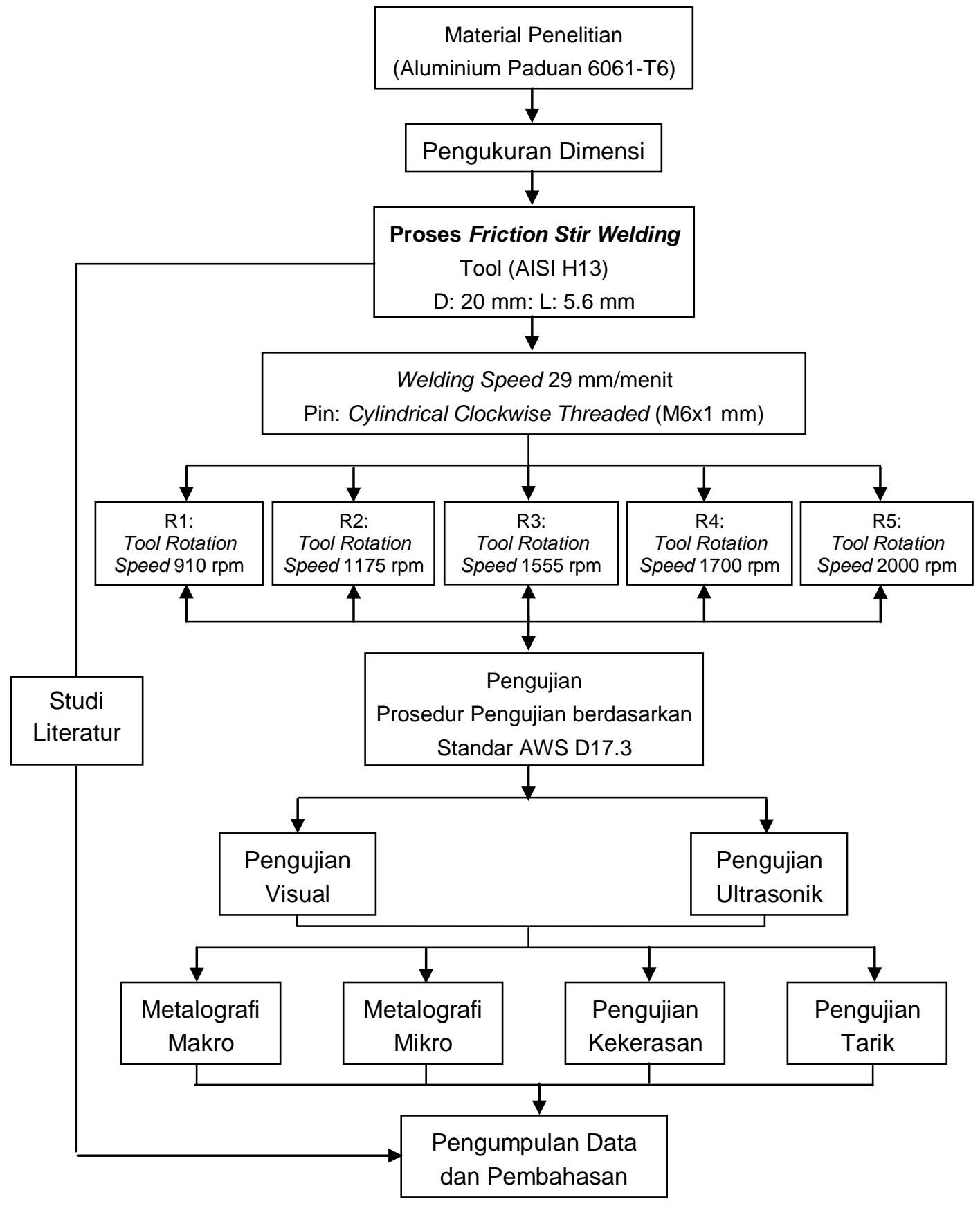

Gambar 2. Diagram alir penelitian FSW alumunium 6061-T6 


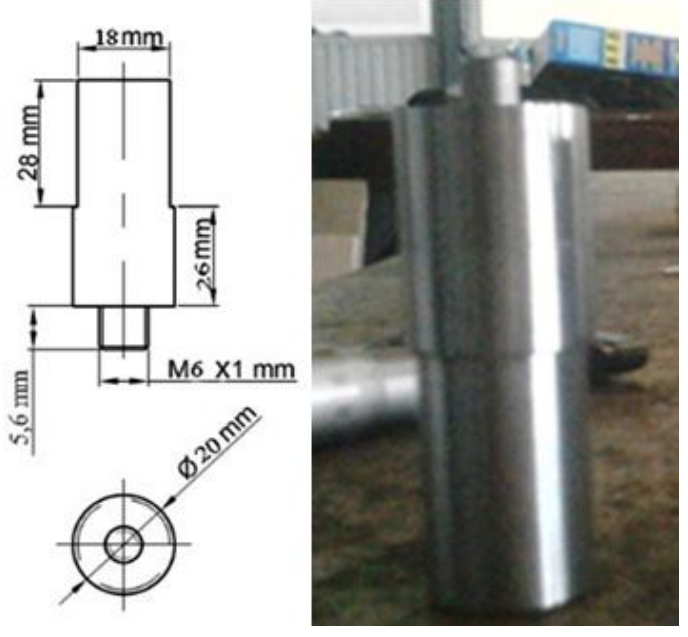

Gambar 3. Desain tool proses FSW pada alumunium 6061-T6

Setelah pengujian secara visual maka dilakukan pengujian ultrasonik menggunakan mesin CTS-2020E dengan resolusi $0,1 \mathrm{~mm}$ untuk melihat adanya indikasi cacat di dalam spesimen uji. Pengujian selanjutnya adalah metalografi dimulai dengan pemotongan spesimen, dimounting dan kemudian diamplas sampai halus menggunakan amplas nomor 2000 dan polishing sebelum dicelupkan ke dalam larutan etsa keller's reagent untuk melihat daerah lasan dan sekitarnya secara makro dan mikro menggunakan mikroskop optik. Untuk menentukan fasa yang muncul pada daerah lasan merujuk pada ASM Metal Handbook[17]. Pengukuran kekerasan dilakukan 2 titik pada masing-masing area dan percobaan dengan jarak $1 \mathrm{~mm}$ menggunakan metode microhardness vickers dengan beban 50 gram serta ditahan sekitar 13-15 detik[18]. Terakhir dilakukan pengujian tarik untuk mengetahui kuat tarik daerah sambungan. Jumlah dan posisi pengambilan sampel uji tarik mengacu pada standar AWS D 17.3[19].

\section{HASIL DAN PEMBAHASAN}

\section{Analisis Visual Hasil Pengelasan}

Berdasarkan Percobaan yang telah dilakukan pada 5 spesimen, pemeriksaan Visual menunjukan bahwa pada bagian face terdapat flash yang terbentuk di seluruh spesimen, seperti ditunjukan pada Gambar 4.
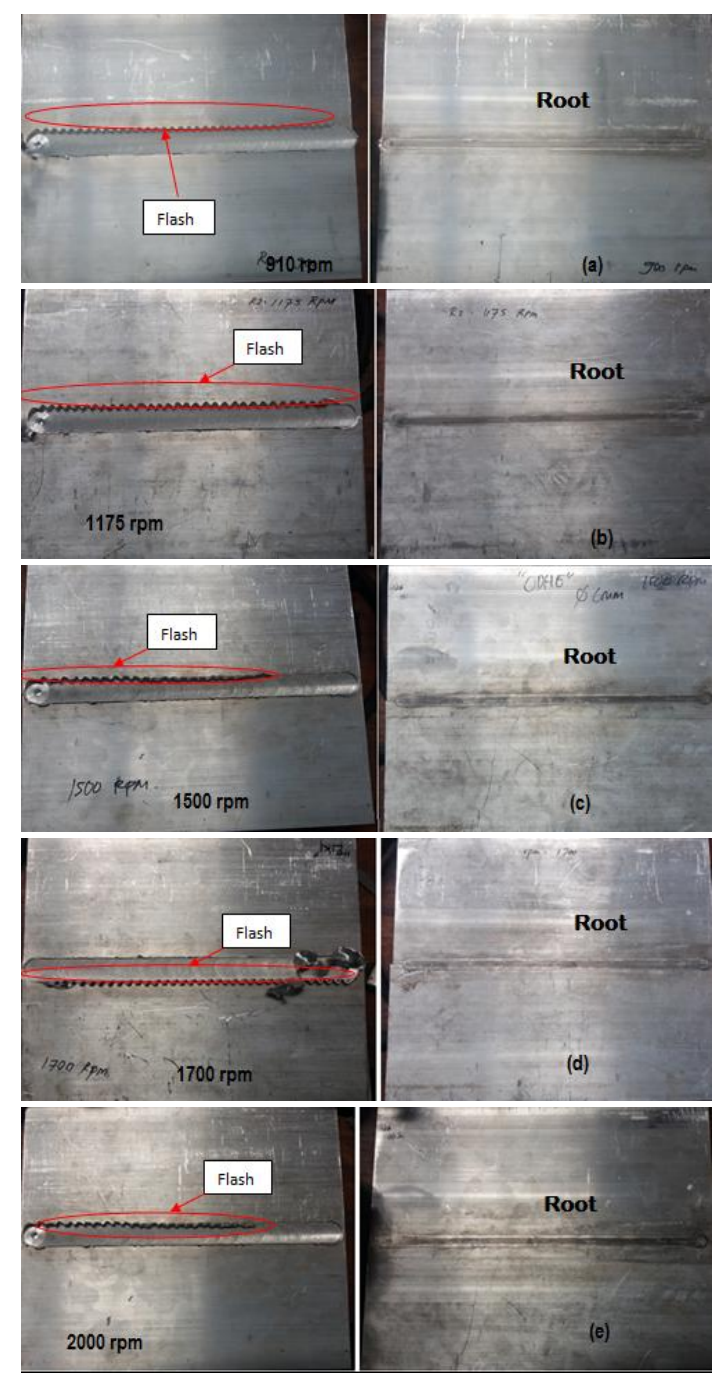

Gambar 4. Hasil visual FSW alumunium 6061-T6

Flash yang muncul diakibatkan karena adanya heat input berlebih. Secara skematis flash terbentuk akibat oleh dorongan dari shoulder pada permukaan benda kerja dan penekanan tool yang terlalu dalam sehingga logam pada bagian samping dinding tool terdorong keluar dan terangkat membentuk flash. Berdasarkan standar AWS D 17.3 [17] seluruh flash dapat dihilangkan setelah pemeriksaan visual dan sebelum dilakukan pemeriksaan non-destructive test (NDT) dengan metode yang tidak menurunkan sifat dari weld joint atau logam induk. Sedangkan 
pada bagian root, seluruh benda uji tidak terdapat cacat karena logam mengisi seluruhnya celah antara kedua benda kerja yang disambung.

\section{Analisis Hasil Uji Ultrasonik}

Pengujian Ultrasonik untuk mengetahui cacat di dalam permukaan benda kerja ditunjukkan oleh Gambar 5 dengan sumbu $Y$ menandakan peak echo dan sumbu $X$ menunjukkan ketebalan atau kedalaman indikasi adanya cacat. Hasil uji ultrasonik menunjukkan bahwa spesimen uji dengan kecepatan putar 910, 1175 dan 1555 rpm tidak ditemukan adanya indikasi cacat, sedangkan pada spesimen dengan kecepatan putar 1700 dan 200 rpm ditemukan adanya indikasi cacat seperti terlihat dari adanya crack echo pada layar monitor uji ultrasonik untuk spesimen pengujian dengan kecepatan putar 1700 dan 2000 rpm.

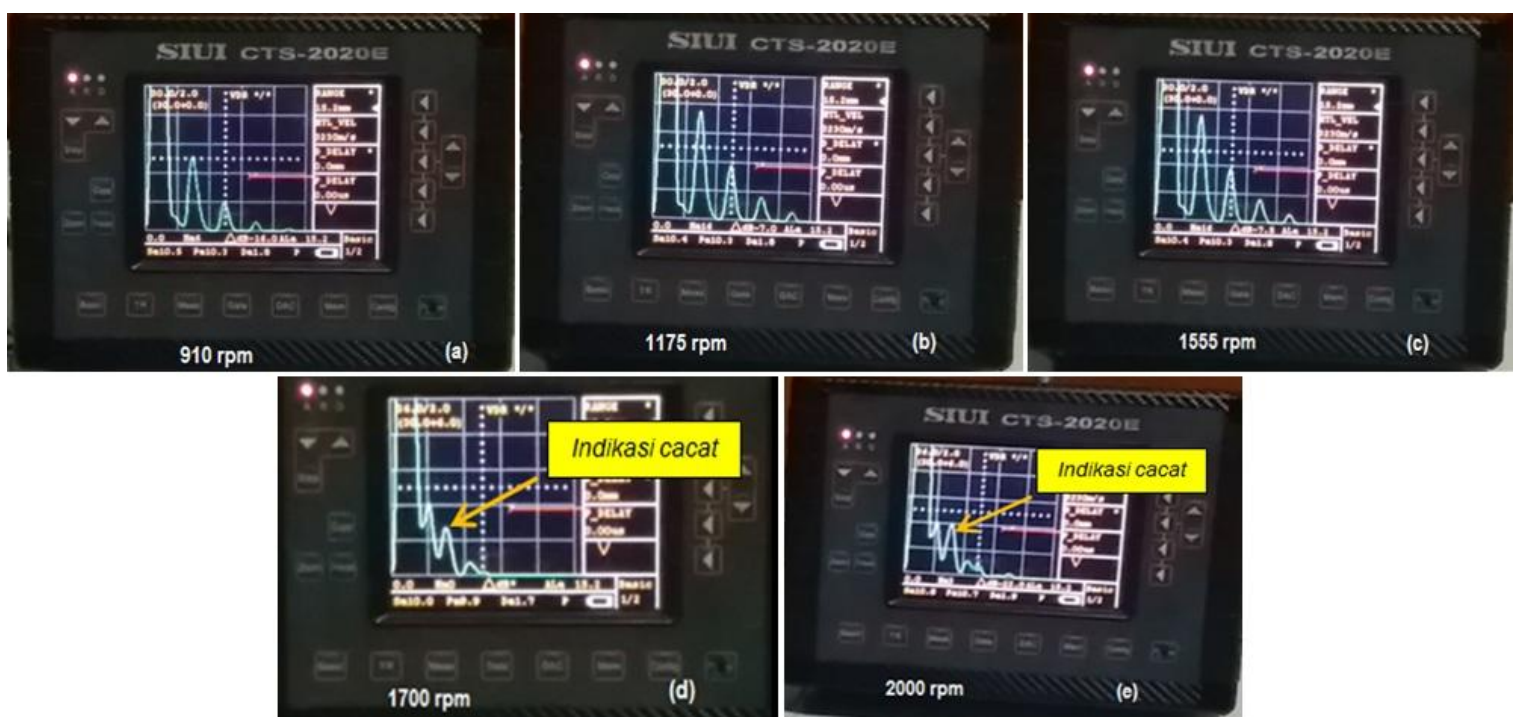

Gambar 5. Hasil uji Ultrasonik FSW alumunium 6061-T6

\section{Analisis Hasil Metalografi Makro}

Hasil pengujian metalografi makro terlihat pada Gambar 6. Pengujian metalografi makro bertujuan untuk mengetahui daerah lasan yang terbentuk dari hasil pengelasan dan mengetahui cacat. Berdasarkan pengujian makro bahwa terdapat empat daerah lasan yang berbeda, yaitu daerah stir zone, TMAZ, HAZ, dan base metal [14]. Sedangkan cacat yang ada terlihat lebih jelas secara hasil foto makro.

Hasil foto makro dapat memperjelas dimensi cacat secara kualitatif, pada benda uji dengan kecepatan putar $1700 \mathrm{rpm}$ memiliki cacat dengan luas daerah lebih kecil dibandingkan benda uji dengan kecepatan putar 2000 rpm, sedangkan pada benda uji lainnya dimana kecepatan putar tool-nya lebih rendah tidak terdapat cacat. Dalam hal ini terdapat hubungan bahwa semakin tinggi kecepatan putar tool, maka potensi terjadinya cacat semakin besar[20]. Adanya cacat tunnel dan cacat cavitypada hasil proses FSW menunjukkan spesimen tidak lolos uji karena tidak memenuhi batasan penerimaan cacat berdasarkan standar AWS D 17.3[19]. Oleh karena itu berdasarkan standar tersebut, maka spesimen uji yang memenuhi kriteria adalah benda uji dengan kecepatan 910, 1175 dan $1555 \mathrm{rpm}$. 

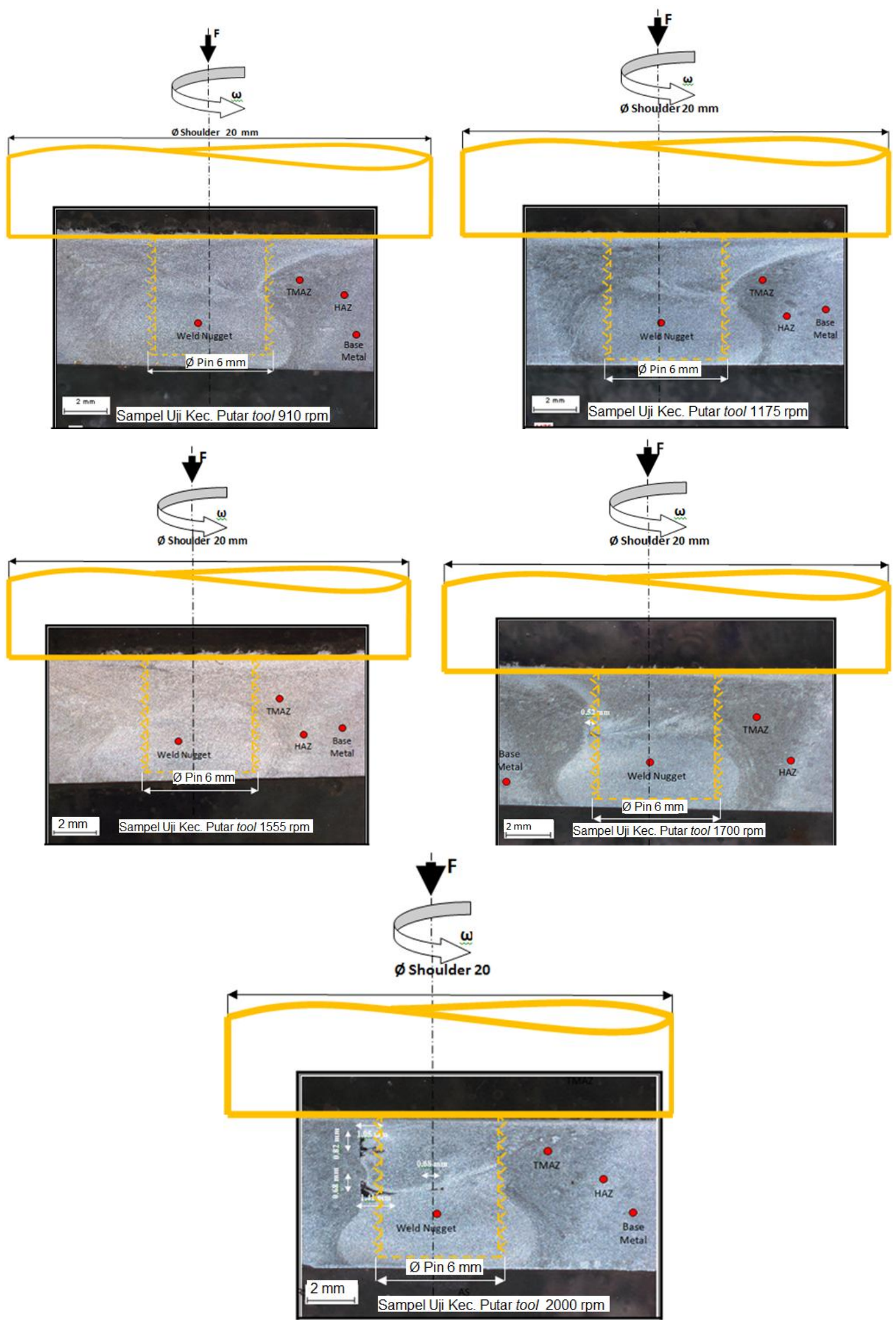

Gambar 6. Hasil uji makro FSW alumunium 6061-T6 


\section{Analisis Hasil Metalografi Mikro}

Setelah dilakukan pengamatan makro dilanjutkan dengan pengujian struktur mikro dan pengujian ini dilakukan untuk mengetahui fasa yang terbentuk. Pada spesimen hasil lasan terdapat daerah yang terbentuk yaitu Base Metal, Heat Affected Zone dan Stir Zone seperti ditunjukkan Gambar 7. Pada seluruh benda uji terlihat perbedaan struktur mikro pada tiap daerah hasil lasan. Dimana pada daerah stir zone memiliki kekasaran butir paling halus. Ketegangan ekstrim dan suhu tinggi yang terjadi menyebabkan rekristalisasi material dalam stir zone menghasilkan butir yang relative halus dan relatif kecil dibandingkan dengan daerah lainnya[19].

TMAZ dideskripsikan bagian-bagian manapun yang mengalami pemanasan tetapi belum tertutup oleh stir zone [22] sedangkan daerah HAZ ditandai dengan tidak terjadinya deformasi plastis tetapi masih dipengaruhi oleh panas akibat proses yang terjadi di weld zone[23]. Berdasarkan perhitungan besar butir dengan menggunakan metode Heyn didapatkan bahwa ukuran butir yang paling kecil adalah spesimen dengan kecepatan putar $910 \mathrm{rpm}$ dan yang paling besar adalah spesimen dengan kecepatan putar 2000 rpm.

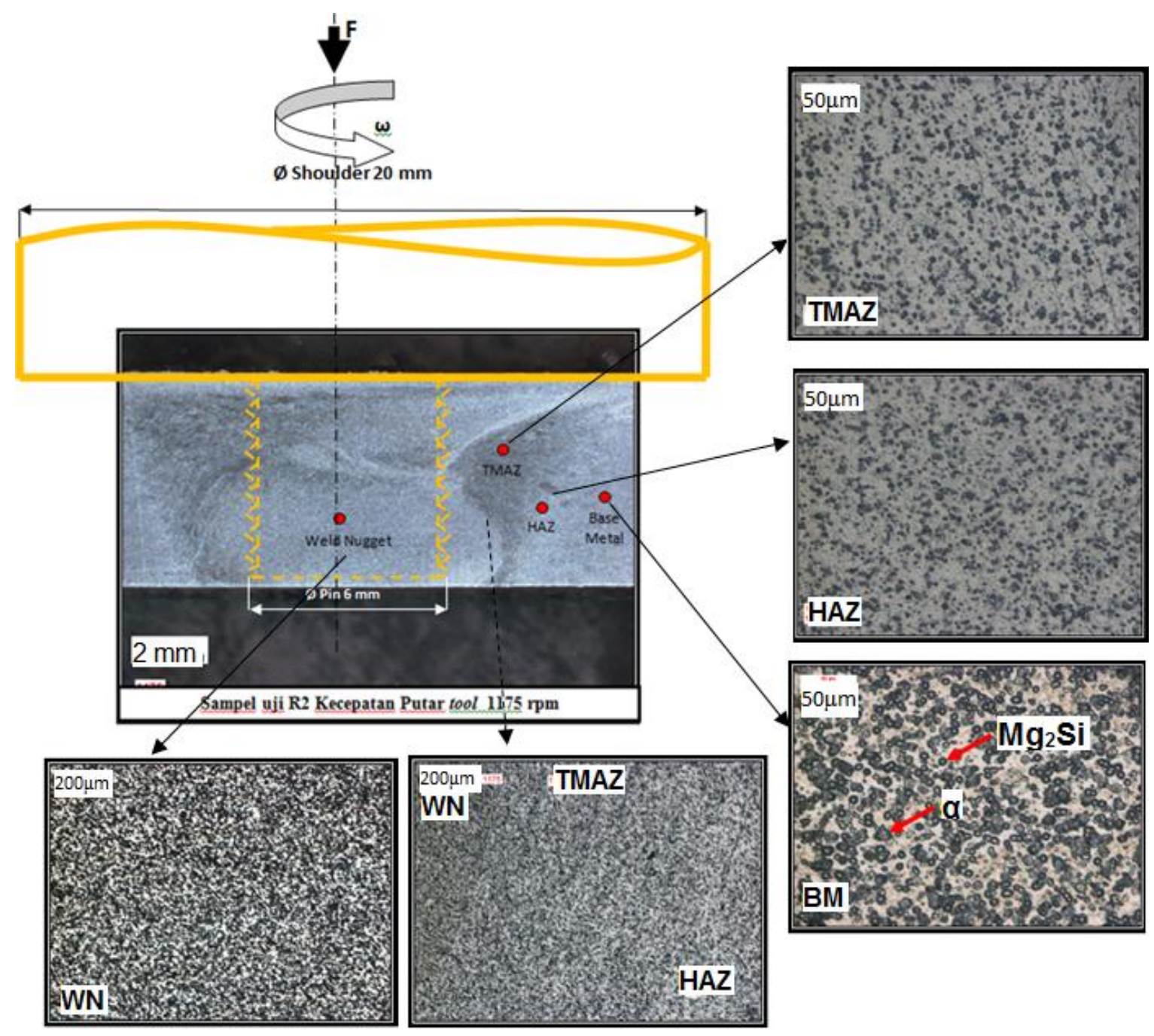

Gambar 7. Struktur makro dan mikro hasil FSW alumunium 6061-T6 dengan kecepatan putar $1175 \mathrm{rpm}$ yang dietsa dengan Keller's reagent 


\section{Analisis Hasil Uji Kekerasan}

Pengujian berikutnya dilanjutkan dengan uji kekerasan pada daerah tanpa cacat, menggunakan metode mikro vikers dengan beban penekanan 50 gram, pengujian dilakukan pada setiap daerah lasan. Berdasarkan hasil pengujian kekerasan pada seluruh benda uji seperti ditunjukkan pada Gambar 8. Berdasarkan data tersebut terjadi perbedaan nilai kekerasan pada tiap daerah lasan setelah dilakukan proses friction stir welding. Kekerasan base metal adalah 81,73 HV sedangkan daerah lasan lainya nilai kekerasan yang paling tinggi adalah spesimen R1 (910 rpm) dengan nilai kekerasan HAZ 49,07 HV, TMAZ 64,01 HV, Stir zone 71,92 HV. Jika dikomparasikan setiap kecepatan putaran tool bahwa semakin tinggi kecepatan tool maka temperatur juga semakin tinggi. Semakin tinggi temperatur yang dihasilkan maka berpotensi terjadinya softening (pelunakan) sehingga kekerasan didaerah lasan akan mengalami penurunan [24].

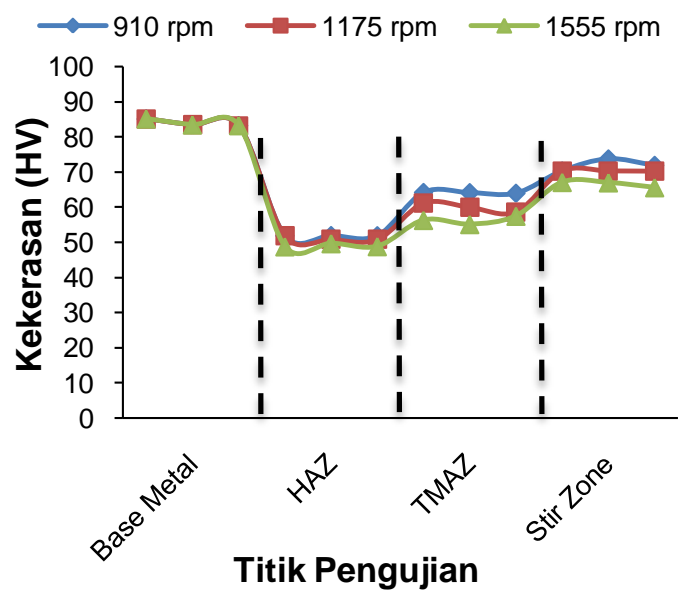

Gambar 8. Nilai Kekerasan FSW alumunium 6061-T6

\section{Analisis Hasil Uji Tarik}

Gambar 9 memperlihatkan bahwa spesimen uji dengan kecepatan putar 910 rpm memiliki kekuatan tarik paling optimum dibandingkan dengan specimen uji lainya yaitu sebesar $146 \mathrm{~N} / \mathrm{mm}^{2}$ sebesar $53 \%$ dari kekuatan tarik base metalnya. Dapat dilihat bahwa secara rata-rata kekuatan tarik mencapai nilai maksimum ketika kecepatan putar meningkat dari 910 menjadi 1175 rpm dan kemudian kekuatan tarik menurun dengan meningkatnya kecepatan putar.

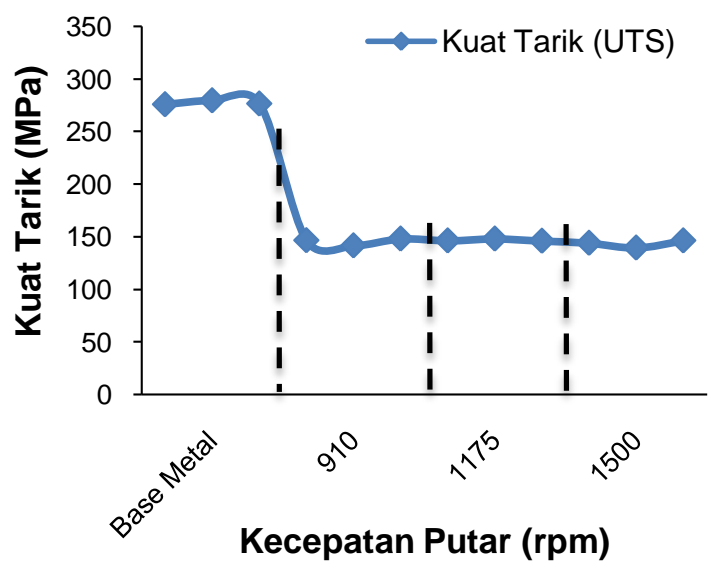

Gambar 9. Nilai Kuat Tarik FSW alumunium 6061-T6

Kenaikan kecepatan putar dari 910 rpm menjadi 1175 rpm akan meningkatkan kekuatan tarik sampai pada nilai optimum dan kemudian akan menurun dengan naiknya kecepatan putar menjadi $1555 \mathrm{rpm}$. Kondisi ini terjadi karena heat input yang lebih tinggi akan meningkatkan ukuran butir dan terputusnya partikel Mg2Si fase kedua pada Stir Zone aluminium 6061-T6 dengan kecepatan putar yang lebih tinggi akan menurunkan kekuatan tariknya[25],[26].

Ukuran butir base metal secara umum lebih kecil dibanding dengan dengan stir zone sehingga kekuatan tarik dari basemetal akan lebih tinggi dibanding sambungan las, hal ini terjadi karena seiring dengan meningkatnya temperatur, presipitat yang terdapat dalam aluminium bisa terjadi pengkasaran atau bahkan larut dalam matriks aluminium sehingga hal ini akan berdampak pada kekuatan tarik sambungan. Selain itu ukuran butir akan mempengaruhi kekuatan dari sambungan sebagaimana yang dinyatakan oleh persamaan hall patch, dimana semakin besar butir semakin turun kekuatan suatu material[27]. 


\section{SIMPULAN}

Proses Friction Stir Welding (FSW) aluminium seri 6061-T6 ketebalan $6 \mathrm{~mm}$ dengan ukuran $305 \mathrm{~mm} \times 125 \mathrm{~mm}$ dan tipe sambungan butt joint menggunakan tool cylinder threaded dengan variasi kecepatan putar 910, 1175, 1555, 1700 dan 2000 rpm serta kecepatan pengelasan yang digunakan $29 \mathrm{~mm} / \mathrm{min}$ telah berhasil dilakukan dengan hasil yang optimum ditunjukkan oleh spesimen menggunakan kecepatan putar $910 \mathrm{rpm}$. Hasil kuat tarik dan kekerasan maksimum yang dihasilkan adalah $146 \mathrm{~N} / \mathrm{mm}^{2}$ dan 71,92 HV. Hasil sambungan juga menunjukkan bahwa tidak terjadi cacat yang dapat dilihat dari uji ultrasonik dan metalografi. Sedangkan spesimen uji menggunakan kecepatan putar 1700 dan 2000 rpm terdapat cacat pada sambungan. Proses Friction Stir Welding (FSW) aluminium seri 6061-T6 menggunakan kecepatan putar 910 rpm menunjukkan sifat mekanik dan struktur mikro yang lebih baik dibandingkan mengunakan kecepatan putar 1175, 1555, 1700 dan 2000 rpm

\section{UCAPAN TERIMA KASIH}

Penulis mengucapkan terima kasih yang sebesar-besarnya Bapak Dr. Ing Ir. Supono Adi Dwiwanto, yang telah meluangkan waktu untuk memberikan saran dalam penelitian dan penulisan makalah ini serta kepada Staf Seksi Pemesinan dan Pengelasan BBLM yang menyediakan fasilitas untuk penelitian ini.

\section{DAFTAR PUSTAKA}

[1]. A. Sudrajat, "Analisis sifat mekanik hasil pengelasan aluminium Aa 1100 dengan metode friction stir welding," Skripsi Jurusan Teknik Mesin Universitas Jember, vol. 1, pp. 8-17, 2012.

[2]. IAEA, Corrosion of research reactor aluminium clad spent fuel in water. IAEA, 2009.

[3]. E. Taban and E. Kaluc, "Comparison between microstructure characteristics and joint performance of 5086- 332 aluminium alloy welded by MIG, TIG and friction stir welding processes," Kovove Materialy, vol. 45, pp. 241-248, 2007.

[4]. R. F. A. Wahid, Irfan, and Tarmizi, "Pengaruh kecepatan pengelasan terhadap sifat mekanik sambungan alumunium paduan 5052-H32 pada proses friction stir welding," Metalurgi, vol. 34, no. 2018, pp. 9-18, 2019.

[5]. A. A. Jarot Wijayanto, "Pengaruh feed rate terhadap sifat mekanik pada pengelasan friction stir welding alumunium 6110," Jurnal Kompetensi Teknik, vol. 2, no. 1, pp. 19-28, 2010.

[6]. M. A. Wahid, Z. A. Khan, and A. N. Siddiquee, "Review on underwater friction stir welding: A variant of friction stir welding with great potential of improving joint properties," Transaction of Nonferrous Metals Society of China, vol. 28, no. 2, pp. 193-219, 2018.

[7]. S. K. Tiwari, D. K. Shukla, and R. Chandra, "Friction stir welding of aluminum alloys: A review," International Journal of Mechanical Aerospace Industrial Mechatronic and Manufacturing Engineering, vol. 7, no. 12, pp. 1326-1331, 2013.

[8]. L. M. Serio, D. Palumbo, L. A. C. De Filippis, U. Galietti, and A. D. Ludovico, "Effect of friction stir process parameters on the mechanical and thermal behavior of $5754-\mathrm{H} 111$ aluminum plates," Materials (Basel)., vol. 9, no. 3, 2016.

[9]. J. M. S. Al-murshdy and Q. K. N. Chabuk, "Effect of tool shape geometry and rotation speed in friction stir welding of 2024-T3," Iraqi Journal of Mechanical Engineering and Materials Engineering, vol. 16, no. 3, pp. 176-185, 2016.

[10]. L. Commin, M. Dumont, J. E. Masse, and L. Barrallier, "Friction stir welding of AZ31 magnesium alloy rolled sheets: 
Influence of processing parameters," Acta Materialia, vol. 57, no. 2, pp. 326-334, 2009.

[11]. N. Shanmuga Sundaram and N. Murugan, "Tensile behavior of dissimilar friction stir welded joints of aluminium alloys," Material and Design, vol. 31, no. 9, pp. 4184-4193, 2010.

[12]. P. Sharma and D. Bhati, "Effects of tool rotation speed and tilt angle on friction stir welding of Al-6075," International Journal on Recent Technologies in Mechanical and Electrical Engineering, vol. 2, no. 8, pp. 60-62, 2015.

[13]. N. Dialami, M. Cervera, and M. Chiumenti, "Effect of the tool tilt angle on the heat generation and the material flow in friction stir welding," Metals (Basel)., vol. 9, no. 1, pp. 28, 2018.

[14]. J. Q. N. Li and H. J. Liu, "Effects of welding speed on microstructures and mechanical properties of AA2219-T6 welded by the reverse dual-rotation friction stir welding," International Journal of Advanced Manufacturing Technology, vol. 68, no. 9-12, pp. 2071-2083, 2013.

[15]. A. Nurhafid, S. Jokosisworo, U. Budiartool, "Analisa pengaruh perbedaan feed rate terhadap kekuatan tarik dan impak aluminium 6061 metode pengelasan friction stir welding," Jurnal Teknik Perkapalan, vol. 5, no. 2, pp. 473-481, 2017.

[16]. N. Çapar, U. Kumru, T. A. BaŞer, Gö. Tekin, and O. Saray, "Friction stir spot welding for automotive applications," International Journal Automotive Technology and Management, vol. 1, no. 3, pp. 114-118, 2017.

[17].M. Warmuzek and I. Alloys, "Metallographic Techniques for Aluminum and Its Alloys," Metallography, Microstructure, and Analysis vol. 9, pp. 711-751, 2018.

[18]. ASTM E 384, "Standard Test Method for Knoop and Vickers Hardness of Materials 1," 2012.
[19]. “AWS_D17.3-D17.3M-1.” 2010.

[20]. P. J. Ramulu, R. G. Narayanan, S. V. Kailas, and J. Reddy, "Internal defect and process parameter analysis during friction stir welding of Al 6061 sheets," International Journal of Advanced Manufacturing Technology, vol. 65, no. 9-12, pp. 1515-1528, 2013.

[21]. J. A. B. Nilesh Kumar, Rajiv S. Mishra, Residual Stresses in Friction Stir Welding Residual Stresses in Friction Stir Welding. 2014.

[22]. I. Radisavljevic, A. Zivkovic, N. Radovic, and V. Grabulov, "Influence of FSW parameters on formation quality and mechanical properties of Al 2024T351 butt welded joints," Transaction of Nonferrous Metals Society of China, vol. 23, no. 12, pp. 3525-3539, 2013.

[23]. R. W. Fonda and J. F. Bingert, Microstructural evolution in the heataffected zone of a friction stir weld, vol. 35 A, no. 5. 2004.

[24].J. S. Leon and V. Jayakumar, "Investigation of mechanical properties of aluminium 6061 alloy friction stir welding," International Journal of Students Research in Technology and Management, vol. 2, no. 4, pp. 140-144, 2015.

[25].W. Woo and H. Choo, "Softening behaviour of friction stir welded $\mathrm{Al}$ 6061-T6 and Mg AZ31B alloys," Science and Technology of Welding and Joining, vol. 16, no. 2, pp. 267-272, 2011.

[26]. J. He, Z. Ling, and H. Li, "Effect of tool rotational speed on residual stress, microstructure, and tensile properties of friction stir welded 6061-T6 aluminum alloy thick plate," International Journal of Advanced Manufacturing Technology, vol. 84, no. 9-12, pp. 1953-1961, 2016.

[27]. R. S. Mishra and Z. Y. Ma, "Friction stir welding and processing," Materials Science and Engineering Reports, vol. 50, no. 1-2, pp. 1-78, 2005. 